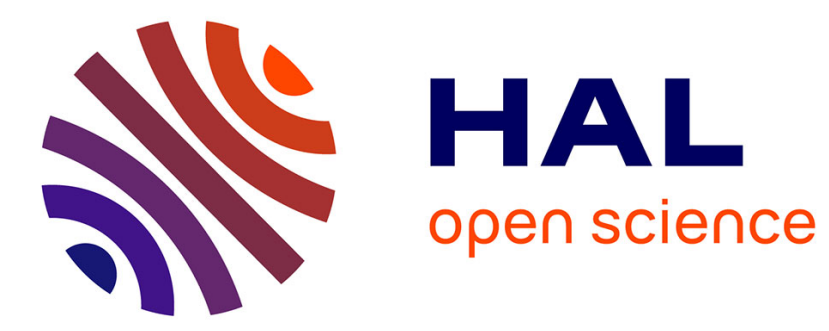

\title{
Trade impact of European measures on GMOs condemned by the WTO panel
}

\author{
Anne-Célia Disdier, Lionel Fontagné
}

\section{To cite this version:}

Anne-Célia Disdier, Lionel Fontagné. Trade impact of European measures on GMOs condemned by the WTO panel. Review of World Economics, 2010, 146 (3), pp.495-514. 10.1007/s10290-010-0057-7 . hal-00594967

\section{HAL Id: hal-00594967 \\ https://hal.science/hal-00594967}

Submitted on 23 May 2011

HAL is a multi-disciplinary open access archive for the deposit and dissemination of scientific research documents, whether they are published or not. The documents may come from teaching and research institutions in France or abroad, or from public or private research centers.
L'archive ouverte pluridisciplinaire HAL, est destinée au dépôt et à la diffusion de documents scientifiques de niveau recherche, publiés ou non, émanant des établissements d'enseignement et de recherche français ou étrangers, des laboratoires publics ou privés. 


\title{
Trade Impact of European Measures on GMOs
}

\section{Condemned by the WTO Panel}

\author{
Anne-Célia Disdier (INRA, UMR Economie Publique INRA-AgroParisTech) \\ Lionel Fontagné (Paris School of Economics, Université Paris I and CEPII)
}

\begin{abstract}
Affiliations and addresses:
Corresponding author: Anne-Célia Disdier: 16 rue Claude Bernard, 75231 Paris Cedex 05, France.

Email: anne-celia.disdier@agroparistech.fr. Tel: +3314408 72 72. Fax: + 33144081663.

Lionel Fontagné: Maison des Sciences Economiques, 106-112 Bd de 1'Hôpital, 75647 Paris Cedex 13, France.
\end{abstract}

\begin{abstract}
In May 2003, the United States, Canada and Argentina launched a World Trade Organization (WTO) case against the European Union concerning its authorization regime for genetically modified organisms (GMOs). The complainants challenged three types of measures: (i) an alleged general moratorium on the approval of GMOs; (ii) delays in the processing of product specific applications; (iii) national safeguard measures adopted by certain Member States banning the marketing of certain genetically modified products. In November 2006, the WTO condemned the European regime. Using the most recent advances in gravity equation, we estimate the reduction in exports of potentially affected products from the complainants to the European Union. Export losses are calculated by product, complainant country and measure at stake. Our results tend to confirm the foundations of the dispute: the European moratorium and product-specific measures have a negative effect on trade, as do safeguard measures adopted by Germany, Italy and Greece.
\end{abstract}

Keywords: International trade, WTO panel, genetically modified organisms, gravity.

JEL codes: F13, Q17 


\section{Introduction}

From the beginning of the 90s, the European Union (EU) implemented legislation on genetically modified organisms (GMOs), which was however challenged by major GMO producer and exporting countries: In May 2003, the United States (US), Canada and Argentina launched a case at the World Trade Organization (WTO) against the EU. For the three complainants, the EU policy on GMOs reduced their exports to the EU market. In September 2006, the WTO panel stated in its report that the EU had applied a general de facto moratorium on the approval of GMOs since June 1999 and undue delays in the processing of product-specific applications, and consequently had breached its obligations under the Sanitary and Phytosanitary (SPS) Agreement. The report also concluded that the national safeguard measures put in place by certain EU Members on biotech products that had already been approved as safe by the EU were inconsistent.

The purpose of this paper is to quantify the trade impact of EU measures on GMOs in the perspective of the WTO complaint. ${ }^{1}$ Quite surprisingly, no research has been carried out to date to measure and quantify the potential export losses faced by the three complainants - Argentina, Canada and the US - in the EU market in monetary terms. Accordingly, our main aim is to provide an estimation of the revenue lost from the EU market by complainants. According to WTO dispute settlement practices, this revenue loss is indeed key to defining the magnitude of the retaliatory measures that might be enforced were the Panel's recommendations not implemented by the EU. ${ }^{2}$ It

\footnotetext{
${ }^{1}$ Trade of GMOs is subject to WTO rules. However, it is also regulated by the Cartagena Protocol on Biosafety (which has not been ratified by the US, Argentina and Canada). To date, efforts to harmonize national legislations have partly failed. International harmonization bodies have achieved some success in handling safety approvals; however, there is still strong disagreement on several specific rules, such as labelling regulation, consumer information and international agreements (Gruère 2006).

${ }^{2}$ In WTO legal terms, this principle is described as follows: "In considering what concessions or other obligations to suspend, the complaining party shall take into account (...) the trade in the sector or under the agreement under which the panel or Appellate Body has found a violation or other nullification or impairment, and the importance of such trade to that party. (...) The level of the suspension of concessions or other
} obligations authorized by the DSB [Dispute Settlement Body] shall be equivalent to the level of the nullification 
could be argued that European measures against GM products were put in place following consumers' rejection of GMOs. However, one has to remind that WTO rules do not state that the preferences of consumers justify regulatory measures affecting trade. These rules only state that any trade-impeding decision must be based on scientific evidence. Hence, applying bans without providing such evidence might well not only affect trade but also consumers' preferences. Ultimately, what matters from the point of view of the panel is the impact of the unjustified (according to WTO) regulations on exports of complainants. The decision of the WTO has been criticised on two major grounds: applicability of the SPS Agreement to the EU regulations on GM products (Conrad 2007); interpretation of the acknowledged scientific evidence provided by the EU (Perez 2007);

European measures may have impacted other countries as well. Similarly, complainants may have been affected by other measures than the ones imposed by the EU. We will check, as an extension, whether it is the case or not. Our paper therefore provides two contributions to the literature: First, we focus on the main GM products being grown commercially in the complaining countries and potentially affected by EU measures, and provide an estimation of losses in terms of exports to the EU market by product, complaining country and measure at stake. To perform the estimation and get unbiased results, we make use of the most recent advances in gravity equation estimation. In particular, we try to avoid the most usual misspecifications found in the literature relying on the traditional simplest gravity framework that have been clearly described by Baldwin and Taglioni (2006). The main issue here is the necessary control for unobserved relative prices when it comes to explaining bilateral trade. Baldwin and Taglioni (2006) refer to this as the "the gold medal of classic gravity model mistakes", namely the fact that the bilateral trade costs used as regressors in the estimated equation are correlated with the omitted variable since trade costs enter into these unobserved prices. ${ }^{3}$ The solution generally adopted is to rely on fixed effects by country but here there

\footnotetext{
or impairment" (Source: Article 22, Annex 2 of the WTO Agreement (World Trade Organization 1994). Italics are ours).

${ }^{3}$ The silver medal refers to the averaging of bilateral trade for each pair of countries. The bronze medal refers to the inappropriate deflation of nominal trade values using an aggregate price index.
} 
is an additional difficulty associated with the panel dimension of the data, since relative prices vary over time. Hence, country x year fixed effects should be used instead. We also use the Poisson estimator suggested by Santos Silva and Tenreyro (2006) rather than the ordinary least squares (OLS) estimator. The authors show that heteroskedasticity in the error terms can cause the OLS method to yield biased estimates. They argue that the most robust estimation method for multiplicative equations like gravity is Poisson pseudo-maximum likelihood (PPML). This specification deals adequately with the zero-value observations, since the dependent variable is measured in levels. Furthermore, it provides estimates that are comparable to elasticity estimates from the standard linear-in-logs specification. The second contribution is to investigate, for comparison purposes, the impact of moratoria or non-approvals of GM products adopted by other countries that were not part of the WTO panel, such as New Zealand, Switzerland and Norway on the exporting countries complaining against the EU measures. In the same way, we examine the impact of EU measures on Brazilian exports, even though Brazil did not join the complainants.

This research is related to the broader literature on the economic effects of the introduction of GM products and the costs induced by regulations on authorization and labelling aiming to segregate and preserve the identity of non-GM grains from GM ones. Bullock and Desquilbet (2002) investigate how these costs affect US seed producers, farmers and grain handlers and how they depend on standards defining goods as non-GM. The authors show that most of the costs faced by farmers come from the production process itself, while the handlers' main cost is the cost of dedicating equipment to either GMOs or non-GMOs but never both. Lapan and Moschini (2004) introduce the costs of segregation and identity preservation in a partial-equilibrium, two-country trade model. In their model, seeds of a new GM product are produced by a home-country monopolistic innovator and sold to a competitive farming industry. Consumers in the foreign country can choose between GM and non-GM products and view GM products as inferior in quality. Due to the presence of segregation and identity preservation costs, the introduction of GM products can lower welfare. Furthermore, regulations on imports of GM products, such as labelling requirements or bans, will affect income distribution among trading partners. Moschini et al. (2005) also allow for differentiated demand. The authors distinguish between GM, conventional and organic food and analyse the effects of the introduction of GM 
products. Organic and conventional products, which existed prior to the introduction of GMOs, are horizontally differentiated, while GM and conventional goods are vertically differentiated (GMOs are inferior in quality to conventional food). On the supply side, the authors account for segregation and identity preservation costs. Calibrated simulations show that, due to the associated segregation costs for non-GM products, the introduction of GMOs reduces welfare. However, this introduction benefits producers of organic food. Last but not least, Moschini (2008) provides a detailed review of GM product adoption in the agro-food sector over the fifteen years and further expected development. If GM crops grew very rapidly between 1994 and 2008, future development may be impeded by restrictive regulations adopted in particular by the EU.

The next section provides some statistics on world production and trade of GM products. It also reviews EU legislation on GMOs and summarizes the dispute between the US, Canada and Argentina on the one hand, and the European Communities (EC) and its Member States on the other. In section 3, we describe our data and detail our econometric specification. Section 4 reports the estimation results. Section 5 concludes.

\section{Background}

\subsection{Summary of world production and trade of GM products}

GM technology has been used to develop crops that benefit farmers, such as insect resistant and herbicide tolerant crops. Insect resistance means that pests can be controlled without applying insecticides, while herbicide tolerance means that weeds can be destroyed by applying the herbicide to which the plant is tolerant. In 2008, GM herbicide tolerant crops accounted for $63 \%$ of global GM plantings, while GM insect resistant crops accounted for $15 \%$ and stacked herbicide tolerant and insect resistant crops represented 22\% of global GM plantings (James 2008).

The first commercial GM crops were planted in 1994. In 2008, GM areas reached 125 million hectares in 25 countries. The US is the main producer country with $50 \%$ of the total areas, followed by Argentina (16.8\%), Brazil (12.6\%), Canada (6.1\%), India (6.1\%), China (3.0\%) and Paraguay (2.2\%). 
All other countries ${ }^{4}$ cultivate GM crops on less than 2 million hectares. Furthermore, almost $44 \%$ of GM crops are produced in developing countries.

Main GM products are soybeans, maize, cotton and oilseed rape. In 2008, GM soybeans account for $53 \%$ of global GM crop area, followed by maize (30\%), cotton (12\%) and oilseed rape (5\%) (James 2008). In terms of the share of global plantings for these four crops, GM traits account for 59\% of soybean plantings in 2005 . The shares are $13 \%$ for maize, $27 \%$ for cotton and $18 \%$ for oilseed rape (Brookes and Barfoot 2006).

\subsection{EU Legislation on GMOs}

The EU legislation on GM products has been implemented since the beginning of the 90s and has two main objectives: (i) the protection of human health and the environment and (ii) the free movement of safe GM products in the EU. This legislation has recently been updated and a new legal framework is now in place. ${ }^{5}$ GM food and feed can be marketed only after a scientific evaluation of any risks which they present for human and animal health and for the environment, to be undertaken under the responsibility of the European Food Safety Authority. This evaluation should be followed by a risk management decision by the Community, under a regulatory procedure ensuring close cooperation between the Commission and the Member States (Regulation (EC) 1829/2003). Besides, EU Member States can invoke the safeguard clause and ban the sale and use on their territories of GM products that have obtained a market authorization from the EU. To do so, they should provide evidence that these products are risky for human health and the environment. Furthermore, the EU regulation also requires the traceability and labelling of all GM food and feed products derived from GMOs, regardless of the

\footnotetext{
${ }^{4}$ In decreasing order of hectarage: South Africa, Uruguay, Bolivia, the Philippines, Australia, Mexico, Spain, Chile, Colombia, Honduras, Burkina Faso, the Czech Republic, Romania, Portugal, Germany, Poland, Slovakia, and Egypt.

${ }^{5}$ Details are available at http://ec.europa.eu/food/food/biotechnology/gmfood/index en.htm. Note that other countries also updated their legislations on GMOs (for example, the US legislation on plant-made pharmaceutical production was updated in 2003).
} 
presence or absence of GM material in the final food or feed product. Two exemptions from the traceability and labelling requirements do however exist. First, conventional products with adventitious presence of authorized GM products are not subject to these requirements if the GM content does not exceed the threshold of $0.9 \%$. Second, products obtained from animals fed with GM feed or treated with GM medicinal products, such as meat, milk or eggs, are also exempt from the requirements.

Labelling obligation for GM products is not specific to the EU. Labelling is also mandatory in East Europe, Brazil, China, Russia, Switzerland, Norway, Australia, Japan, South Korea, Saudi Arabia and Thailand (Gruère 2006). The threshold of GM content under which labelling is not required varies from one country to another (5\% or below).

In July 2003, the EU Commission also adopted a recommendation on guidelines for the development of national strategies to ensure the co-existence of GM, traditional and organic crops (2003/556/EC). According to these guidelines, the approaches to co-existence need to be developed in a transparent and cooperative way, based on technical guidelines. Furthermore, co-existence rules should be cost-effective (without going beyond what is necessary to comply with EU threshold levels for GMO labelling) and specific to different types of crop, since the probability of admixture varies from one crop to another.

\subsection{Summary of the trade dispute to date}

The dispute between the US, Canada and Argentina on the one hand, and the EU and its Member States on the other, on the approval and marketing of biotech products by the EU covers a relatively long time period. On May 13 and 14, 2003, the US, Canada and Argentina launched the WTO case against the EU by requesting consultations concerning the measures adopted by the EU. The consultations did not allow the dispute to be solved and in August 2003, the complainants requested the establishment of a dispute settlement panel set up on March 4, 2004. Over the course of the dispute, tons of documents were submitted by the disputing parties, as well as by the six independent 
scientific experts whose opinion was requested. The Panel report ${ }^{6}$ was postponed several times and finally delivered on September 29, 2006, and adopted by the Dispute Settlement Body of the WTO on November 21, 2006. In a nutshell, the EU was condemned for not having respected the binding framework of the SPS agreement.

The SPS agreement aims to prevent unnecessary trade barriers to agricultural products, while recognizing the right of countries to set their own standards. In order to avoid situations where sanitary or phytosanitary requirements are used as disguised protectionism, countries are invited to enforce measures in line with existing international standards or to provide scientific evidence regarding health concerns otherwise. Various articles of this agreement were held against the EU by the Panel. According to Articles 5.1, 5.5 and 5.6, SPS measures must be based on scientific assessment taking into account risk assessment techniques developed by international organizations, should avoid arbitrariness and should take into account economic feasibility. According to Articles 2.2 and 2.3, countries shall ensure that measures are applied only to the extent necessary to reach their protection purpose and should not be applied in a discriminatory or protectionist manner. Annex B(1) and Article 7 insist on the transparency of the regulations adopted, including the necessity to publish promptly the measures. Annex C(1)(a) first clause and Article 8 condemn undue delays in the approval procedures of contaminants.

The EU announced its intention to conform to the Panel's recommendations, but subject to a reasonable period of time. In June 2007, the complainant countries and the EU agreed that this period would be twelve months from the date of adoption of the Panel report. This deadline was postponed several times. The US and the EU held their seventh technical meeting on GM issues on October 2223, 2008, and discussions continue between the parties since. Furthermore, Argentina and the EU mutually agreed to extend the reasonable period of time for implementation of the Panel's recommendations so as to expire on February 28, 2010. Lastly, Canada and the EU reached a mutually agreed solution on July 2009. Both countries established a bilateral dialogue on agricultural biotech market access issues of mutual interest with bi-annually meetings.

\footnotetext{
${ }^{6}$ Panel report is available at: http://www.wto.org/english/tratop_e/dispu_e/dispu_e.htm
} 
We now summarise the detail of the conclusions of the Panel report, which will constitute the very basis of our empirical estimation below. Three types of measures were challenged by the complainants:

- The general moratorium on the approval of GMOs implemented in June 1999 and considered by complainants as inconsistent with the SPS agreement. The EU failed to have new biotech products entering the approval procedures after June 1999;

- Delays in the processing of product-specific applications. The EU failed to consider for final approval applications concerning certain specified biotech products for which it had commenced approval procedures;

- Safeguard clauses adopted by certain Member States banning the marketing of certain GMO products.

The first series of conclusions concerned the inconsistency of the moratorium with respect to the SPS agreement. The report (World Trade Organization 2006) concluded that the EU applied a general de facto moratorium on the approval of biotech products between June 1999 and August 2003, which was conflicting with rules of the SPS agreement. ${ }^{7}$ Importantly, the Panel concluded that Argentina failed to establish that the EU did not take account of Argentina's special needs as a developing country Member (Article 10.1 of the SPS Agreement concerning special and differential treatment to be conceded to developing economies). Given these conclusions and the fact that Argentina did not claim the general moratorium was inconsistent with provisions concerning delays in approval procedures, Argentina's complaint about this measure was not upheld by the Panel.

\footnotetext{
${ }^{7}$ Annex C(1)(a) first clause and Article 8 of the Agreement have been infringed by the EU. However, the moratorium cannot be considered an SPS measure within the meaning of Articles 2.2, 2.3, 5.1, 5.5, 5.6, 7 and Annex B(1) of the SPS Agreement.
} 
The second series of conclusions concerned product-specific applications. The Panel concluded that there were indeed undue delays in the completion of the approval procedures for 24 products and asked the EU to bring the product-specific measures into conformity with its obligations. ${ }^{8}$

Finally, the Panel also condemned the safeguard measures adopted by Austria, France, Germany, Greece, Italy and Luxembourg on certain products because they were not based on a risk assessment satisfying the definition of the SPS Agreement. ${ }^{9}$ None of the national bans were removed until 2005, the last year included in our empirical analysis, despite repeated requests by the European Commission to lift them. ${ }^{10}$

\section{Data and econometric specification}

\subsection{Data}

Our study focuses on the main GM crops grown commercially and potentially affected by EU authorization procedures (e.g. moratorium, product-specific applications, and safeguard measures), namely maize, cotton and oilseed rape. We exclude soybeans from the sample of GM products affected by EU procedures. RoundUp Ready is the only GM soybean product commercially grown and was approved for import and use in food and feed by the EU before the 1999 moratorium (United States Department of Agriculture 2000). Furthermore, we also include corn gluten in our estimations. Corn gluten is a product derived from corn and therefore subject to the same authorization procedures as corn.

We cover the period from 1994 to 2005 . We start two years before the significant increase in world production of GMOs and the adoption by the EU of the first restrictions on these products.

\footnotetext{
${ }^{8}$ The EU acted inconsistently with its obligations under Annex C(1)(a) first clause and Article 8 of the SPS Agreement. Other claims under the SPS Agreement were rejected by the Panel.

${ }^{9}$ Articles 2.2 and 5.1 of the SPS Agreement were infringed accordingly. As Belgium and Luxembourg are aggregated in our sample, we will not consider the Luxembourg's ban in our empirical application.
} 
Thus, by observing trade flows both before and after the replacement of non-GM crops by GM ones and the implementation of European procedures, we can investigate whether these procedures had an impact on bilateral trade flows. Our trade data come from the BACI database (Base pour l'Analyse du Commerce International - World Database of International Trade) developed by the CEPII (Centre d'Etudes Prospectives et d'Informations Internationales - French Centre for International Economic Studies). This database uses original procedures to harmonise COMTRADE data (Commodity Trade Statistics Database). ${ }^{11}$ We work at the 6-digit level of the Harmonized System of products classification (hereafter HS) and consider the following headings (in HS 2002):

- HS 100510: Maize (seeds);

- $\quad$ HS 100590: Maize (other);

- HS 120510: Rape or colza seeds, whether or not broken (low erucic acid rape or canola seeds);

- HS 120590: Rape or colza seeds, whether or not broken (other);

- HS 120720: Cotton seeds;

- HS 230310: Residues of starch manufacture and similar residues;

- HS 230990: Other preparations of a kind used in animal feeding.

The last two codes are for corn gluten. In the 1988 and 1996 versions of the HS classification on which the BACI database is based, both codes HS 120510 and HS 120590 are aggregated in a single code (HS 120500). We therefore also aggregate them in our estimations. ${ }^{12}$ In the world trade statistics, a distinction cannot yet be made within the same HS code between trade flows of GM and non-GM products. However, in the main GM producing countries, non-GM products have often been substituted to a large degree by GM ones. A fall in trade could therefore be interpreted at least partially as the result of the adoption of restrictions against GMOs by the importing countries. Of course,

\footnotetext{
${ }^{10}$ Ultimately, in November 2004, no qualified majority was reached in the Council to ask Member States to lift these measures. In June 2005, the Council voted against a proposal from the Commission, which required the removal of national safeguard measures. See http://europa.eu/rapid/pressReleasesAction.do?reference=IP/05/793 ${ }^{11}$ http://www.cepii.fr/francgraph/bdd/baci.htm

${ }^{12}$ This aggregation does not bias our study. Products belonging to both codes face exactly the same restrictions at the same time and by the same countries.
} 
changes in competitiveness or transaction costs may have played a role too, and this must be disentangled from the trade effects on complaining countries of the GM restrictions. Fortunately, econometrics allows us to deal with such issues.

We restrict our sample to the main exporting and importing countries of maize, oilseed rape and cotton. Our sample of exporters includes Argentina, Canada, the US, Brazil, Australia, China, the Ukraine, Turkey, Romania, Bulgaria, Serbia-Montenegro, Poland, the Czech Republic, Hungary, Lithuania, Chile and South Africa. For cotton, we also consider exports from Benin, the Ivory Cost and Togo (the main exporters of cotton to the EU). The group of importing countries includes each EU Member State, ${ }^{13}$ Norway, Switzerland, Turkey, the Ukraine, Japan, New Zealand, Australia, China, Canada, the US, Argentina, Brazil, Mexico, South Korea, Indonesia and Thailand.

In our empirical application, we consider three different types of GMO events: (i) the general moratorium, which affects US and Canada exports of GM products to the EU, (ii) the product-specific applications for which the Panel concluded on the existence of undue delays in the completion of the approval procedures and (iii) the national safeguard measures. Tables 1 and 2 report details of the latter two types of events. In both tables, we focus on the main GM crops grown commercially and included in our empirical analysis (cf. supra). Table 1 mentions the date of introduction of the product-specific application by the complainant country(ies), the concerned complainant country(ies) (as recognized by the WTO Panel) and the date of approval of the event in the complainant country(ies). The date of EU approval, if any, is also reported. Table 2 provides the list of safeguard measures condemned by the WTO Panel, the date of initiation, the concerned complainant country(ies) (as recognized by the WTO Panel) and the date of approval of the event in the complainant country(ies).

Insert Tables 1 and 2 here

\footnotetext{
${ }^{13}$ Belgium and Luxembourg are aggregated. EU Members are only considered as importing countries. Intra-EU trade flows are therefore not included in our sample.
} 


\subsection{Econometric specification}

In this section, we tackle the trade impact of the measures adopted against GMOs on exports of the complainant countries. Our objective is accordingly to quantify the trade impact of EU measures on GMOs in the very perspective of the conclusions of the WTO panel. Gravity equation offers an appropriate framework for this analysis, provided that the frequent misuses of this methodology are avoided. The gravity equation can be seen as a reduced form of the theoretical trade flow prediction. Our theoretical foundation for trade patterns is the standard new trade monopolistic competition-CES demand-Iceberg costs model introduced by Krugman (1980). Producers operating under increasing returns in each country produce differentiated varieties that they ship, with a cost, to consumers in all countries. Following Redding and Venables (2004), the value of exports for a given product $k^{14}$ from country $i$ to country $j$ in $t$ can be written as follows:

$$
x_{i j t}=n_{i t} p_{i t}^{1-\sigma}\left(T_{i j t}\right)^{1-\sigma} E_{j t} G_{j t}^{\sigma-1}
$$

with $n_{i t}$ and $p_{i t}$ the number of varieties and prices in country $i$ in year $t, E_{j t}$ and $G_{j t}$ being the expenditure and price index of country $j$ in $t$. The variable $T_{i j t}$ represents the iceberg transport costs in year $t$.

A theoretically consistent approach for estimating equation (1) consists in using fixed effects for each exporting and importing country. These fixed effects incorporate size effects, but also the price and number of varieties of the exporting country and the size of demand and the price index of the importing country. This specification overcomes the already mentioned "gold medal" mistake in gravity equations - the failure to consider relative prices. Baldwin and Taglioni (2006) show, however, that in the case of panel data, time-invariant country fixed effects are not sufficient to remove all the related bias: the cross-section bias will be removed but not the time-series bias. To remove the latter,

\footnotetext{
${ }^{14}$ For simplicity, subscript $k$ is omitted in equation (1).
} 
we interact our country fixed effects with year dummies. Furthermore, Santos Silva and Tenreyro (2006) show that the parameters of log-linearized models estimated by OLS as elasticites can be biased in the presence of heteroskedasticity. They suggest using the PPML method to estimate multiplicative equations like (1). In their specification, the dependent variable is measured in levels. However, this specification provides estimates that are comparable to elasticity estimates from the standard linear-in-logs specification. Furthermore, this specification deals adequately with zero-value observations. Our sample includes a high number of zeros $(44,291$ observations over a total of 57,552 , i.e. 77\%). The performance of the PPML estimator in the presence of a large proportion of zeros has been recently questioned in the literature. Using Monte Carlo simulations, Martin and Pham (2008) suggest that the PPML estimator provides biased estimates when zero trade flows are frequent. However, as highlighted by Santos Silva and Tenreyro (2009), the simulations performed by Martin and Pham (2008) are flawed in that the data are not generated by a constant elasticity model. When data are appropriately generated, a large proportion of zeros does not affect the performance of the PPML estimator. We therefore use the PPML estimator. ${ }^{15}$

Transport costs are measured with the bilateral distance. These distances come from the CEPII database ${ }^{16}$ and are defined as the sum of the bilateral distances between the biggest cities of countries, weighted by the population living in those cities. We also include a dummy variable "Common border" set to 1 for pairs of countries that share a border. As well as this, we control for linguistic similarity by including a dummy, equal to one if both countries share an official language. Data is extracted from the above-mentioned CEPII database.

\footnotetext{
${ }^{15}$ Other methods, such as standard OLS (with $\ln (1+$ flow) as the dependent variable) and Tobit, have been suggested in the literature to deal with zero trade flows. To discrimate between these methods properly, one can perform a heteroskedasticity-robust RESET test (Ramsey 1969). In our case, the test rejects models estimated using the OLS and Tobit regressions. Only the estimations using the PPML method pass the test. The Reset statistic is reported in the results section (bottom of Table 3).

${ }^{16} \mathrm{http}: / /$ www.cepii.fr/anglaisgraph/bdd/distances.htm
} 
Our focus in this paper is on the trade impact of EU measures on GMOs on the complainant countries. The presence of a measure potentially affecting exports of complainant countries to the EU is represented by dummy variables. We define two sets of dummies, each associated with different types of EU restrictions:

- The first set is for the EU moratorium and specific measures. The years of implementation of both moratorium and product-specific measures are often very similar. Therefore, to avoid a collinearity problem, we group both types of measures into a common variable.

- The second set of dummies deals with the safeguard measures adopted by certain EU Members.

Our dummies have four dimensions: time, product, exporting country, and importing country. The time dimension is 1994-2005 and the products are the main GM crops grown commercially and potentially affected by EU measures (HS 100510, 100590, 120500, 120720, 230310 and $230990 \mathrm{cf}$. supra). Since we are studying the trade impact of EU measures condemned by the WTO Panel, dummies are defined for bilateral export flows from one complainant country (Argentina, Canada or the US) to an EU Member State. EU Members refer to the 15 EU States (with Belgium and Luxembourg aggregated) between 1994 and 2003 and to the 25 EU States in 2004 and 2005. We assume that the EU moratorium and/or specific measures can affect each bilateral relationship between a complainant country and an EU State.

The dates of approval of GM events in each EU country come from the Agbios database ${ }^{17}$ and are completed with scrutiny of legislation. Our empirical application uses annual data. However, measures on GMOs can be put in place (or lifted) at any time of the year. Thus, the dummy variable is set to one in year $t$ if the restriction is put in place before the middle of year $t$ and set to zero if the restriction is put in place after. The middle of the year is June 30. Furthermore, the dummy variable is automatically set to one for all years following commercial plantings and as long as the measure is in place.

\footnotetext{
${ }^{17}$ http://www.agbios.com/dbase.php
} 
Using these rules, the set of dummy variables for EU moratorium and specific measures is defined as follows:

- EU moratorium and/or specific measures $=1$ for products on which the EU imposes a moratorium and/or product-specific measures and during years of implementation, if the exporter is Argentina, Canada or the US and the importer is one EU Member State; 0 otherwise.

The set of dummies for national bans is built as follows:

- Austria's safeguard measure $=1$ for all products on which Austria adopted a safeguard measure and during the years of the measure's implementation, if the exporter is Argentina, Canada or the US and the importer is Austria; 0 otherwise.

Similarly, we define dummies for the safeguard measures of Germany, Italy, France and Greece.

Our estimated equation is as follows:

$$
x_{i j t}^{k}=\exp \mu_{i t} \mathrm{fe}_{i t}+\lambda_{j t} \mathrm{fe}_{j t}+\delta_{1} \ln d_{i j}+\delta_{2} \operatorname{cbord}_{i j}+\delta_{3} \operatorname{clang}_{i j}+\boldsymbol{\delta}_{\mathbf{4}} \mathbf{G M O s}_{i j t}^{k} \eta_{i j t}^{k}
$$

where $x_{i j t}^{k}$ is the dollar value of country $j$ 's imports from country $i$ in year $t, \mathrm{fe}_{i t}$ are the timevarying exporter fixed effects, $\mathrm{fe}_{j t}$ the time-varying importer fixed effects, $d_{i j}$ the bilateral distance. cbord $_{i j}$ and clang $g_{i j}$ are dummies to control for common border and common language. GMOs ${ }_{i j t}^{k}$ is the vector of dummies accounting for measures on GMOs for product $k$. The vector $\boldsymbol{\delta}_{4}$ represents the estimated coefficients on these variables. $\eta_{i j t}^{k} \equiv \exp \left(\mathrm{u}_{i j t}^{k}\right)$, with $u_{i j t}^{k}$ the error term. Under the assumption that the expectation of $\eta$ conditional on the covariates equals one, the parameters can be estimated consistently using the PPML estimator. We use cluster regressions to deal with the problem of clustering of errors. We do not control for bilateral tariffs, and this for two reasons. First, bilateral tariffs do not vary significantly over time. Second, while yearly data on bilateral tariffs is available in the TRade Analysis and INformation System (TRAINS) database, there are many missing values and 
the data does not include all specific duties, tariff quotas and anti-dumping duties applied by importing countries. In our estimations, the influence of bilateral applied protection is partly captured by country-year fixed effects.

\section{Estimation results}

\subsection{Overall results}

Table 3 presents the results. Column (1) provides estimates of the average trade effect of EU restrictions on GMOs on the three complainant's exports. First, regarding gravity covariates, the distance affects bilateral imports negatively and significantly. Common border and common language variables do not have the expected positive and significant effect. One explanation could be that our products are homogeneous goods. Cultural linkages between trade partners are less important for such goods than for differentiated products (Rauch 1999).

For all products, estimated coefficients on the "EU moratorium and/or product-specific measures" variable are negative and significant. These coefficients can be interpreted as a percentage change in the dependent variable when the dummy variable equals one. Thus, the value -2.24 for maize seeds means that the dependent variable is $89.4 \%$ (exp[-2.24]-1) lower when the dummy variable equals 1 than otherwise. In other words, this econometric specification tends to show that EU measures on GMOs reduce Argentina, Canada and US exports of maize seeds on average by $89.4 \%$. The percentages of the reductions in exports of Argentina, Canada and the US to the EU due to the European moratorium and/or specific measures on GMOs are respectively $71.1 \%$ (exp[-1.24]-1) for maize other than seeds, $99.4 \%$ (exp[-5.17]-1) for oilseed rape, 98.3\% (exp[-4.10]-1) for cotton seeds, $70.5 \%$ (exp[-1.22]-1) for starch residues and $47.3 \%$ (exp[-0.64]-1) for preparations used in animal feed.

Regarding national bans, it appears that only the Austrian ones on maize (seeds and other) and the Italian one on maize seeds do not have a significant impact. All other national safeguard measures affect Argentinean, Canadian and US exports. The impact of the German and Greek measures is particularly high. Exports from Argentina, Canada and the US to Germany are reduced by $97.2 \%$ (exp[-3.56]-1) for maize seeds and by $97.1 \%$ (exp[-3.05]-1) for maize other than seeds. Furthermore, 
oilseed rape exports from the three complainant countries to Greece are reduced by $95.3 \%$ (exp[-3.53]-

$1)$.

\subsection{Estimations by complaining country}

So far, we have tentatively estimated the average impact of regulatory measures on GMOs on the three complainant's exports. One extension of our analysis consists in distinguishing the influence of the EU moratorium and/or product-specific measures on each exporting country and product. To do so, we divide the "EU moratorium and/or specific measures" dummy into three different dummies (one for Argentina, one for Canada and one for the US). ${ }^{18}$ Column (2) of Table 3 describes the results. Argentine exports of maize seeds and corn gluten are not affected by any European product-specific measures. Furthermore, Argentina does not produce GM oilseed rape and Canada does not produce GM cotton. Therefore, no coefficients are estimated for these country/product combinations. Estimated coefficients on all other country/product combinations, except the ones on maize other than seeds for Argentina and on preparations used in animal feeding for the US, are negative and significant at the $1 \%$ level. Strong variations in terms of magnitude are however observable for each product. For example, the estimated coefficient on Canadian exports of maize seeds is equal to -3.94 (export decrease of $98.1 \%$ ), while that on US exports equals -2.14 (export reduction of $88.2 \%$ ). The difference is even bigger for starch residues: the Canadian exports to the EU are reduced by $99.8 \%$ (exp[-6.10]1), while the US ones are reduced by only $67 \%(\exp [-1.11]-1)$.

\subsection{Discussion of the results}

Our exercise aims to address the impact of the condemned measures on complainant countries. Accordingly, three issues must be discussed before computing the revenue lost from the EU market by

\footnotetext{
${ }^{18}$ Each dummy is set to one if the dummy "EU moratorium and/or specific measures" is equal to one and the exporting country is respectively Argentina, Canada and the US. Here, we focus only on "EU moratorium and/or specific measures". The highest revenue losses are indeed due to these measures. This division could also be made for all other measures adopted by the importing countries against GM products but would be less relevant.
} 
complaining countries, along the restrictive lines of the WTO interpretation of the case: i) whether the estimated impact captures the combined impact of the GMO rejection by consumers and condemned measures, or the additional impact of these measures; ii) whether GMO exporters that did not join the panel have also been affected by these measures; and iii) whether complainants' exports have also been affected by measures taken by importers who were not condemned.

Regarding the first question, one may argue that European measures against GM products were put in place following consumers' rejection of GMOs. But the further degradation of EU consumers' opinions regarding GMOs might in this case be self-reinforcing: negative opinion justifies measures that reinforce the adverse sentiment of consumers. Under such circumstances, our econometric strategy would hardly fully disentangle the trade effect of European measures on GMOs from the potential impact of rejection by consumers. However, according to the decision of the WTO panel, what have been breached are the SPS rules. These rules do not state that the preferences of consumers justify regulatory measures affecting trade. On the contrary, what these rules do state is that scientific evidence must be provided in support of any trade-impeding decision that is taken.

A second question is whether other GM producers, which did not challenge EU measures at the WTO, were also affected by these measures. Brazil constitutes the best example for such an investigation. Monsanto's 'Roundup Ready' soybean and Bollgard cotton were approved in Brazil in 2004 and 2005, respectively. As we already mentioned, RR soybean was not affected by EU measures. We therefore focus on cotton and examine whether Brazil's exports to the EU in 2005 were affected by EU measures. To do so, we add Brazil to the group of countries producing GM cotton and subject to EU moratorium and/or specific measures.

One last question is whether complainants have been affected by the restrictions on the authorization of GM products taken by countries outside the EU but nevertheless not concerned by the case. Since November 2005, Switzerland has a 5-year moratorium on the cultivation of GM crops and the import of genetically modified animals. The moratorium does not apply to research into GMOs nor does it stop imports of genetically modified food. Only imports of seeds are affected. Besides, US 
exports of maize and soybeans seem to have been affected by the time lag between the US and Swiss approvals. In 1996, New Zealand put in place a general moratorium, which expired in October 2003. Officially, Norway has never adopted bans or moratoria on GM imports. However, few GM products can be imported into Norway. Imports of GM soybeans (HS 120100) and GM Maize (HS 100590) have not been approved. For comparison purposes, we also investigate the impact of such restrictions.

Column (3) of Table 3 presents the results. The coefficient estimated on Brazil's exports is negative, significant at the $1 \%$ level, and higher than those on Argentinean and US exports. Therefore, we can conclude that Brazilian cotton exports are also reduced by EU restrictions, although Brazil did not launch a WTO case against the EU. The reduction equals 99.5\% (exp[-5.37]-1). Interestingly, our results also show that estimated coefficients on New Zealand's moratorium on maize (seeds), oilseed rape and soybeans and Norway's non-approval for maize other than seeds are also negative and significant. Thus, exports of maize, oilseed rape and soybeans from Argentina, Canada and the US to New Zealand and Norway are also affected by the measures on GMOs put in place in these two importing countries. The percentages of the decreases are respectively $66 \%(\exp [-1.08]-1)$ for maize seed exports to New Zealand, 99.3\% (exp[-4.93]-1) for oilseed rape exports to New Zealand, 94.7\% (exp[-2.93]-1) for soybean exports to New Zealand and 83.8\% (exp[-1.82]-1) for maize other than seed exports to Norway.

Insert Table 3 here

\subsection{Estimates of monetary revenue losses}

Notwithstanding the fact that not all affected countries have joined the case against the EU, revenue losses taken into account in the WTO arbitrage will be limited to the complaining countries Argentina, Canada and the US. The impact of EU measures on GMOs on the exports of these countries can be quantified in monetary terms by using the estimates from Table 3 . When calculating the impact we do not take into account effects on non-complaining countries, nor effects of measures taken by non-EU importers on complainants' exports. Indeed, it could be argued that revenue losses result not only from 
the direct effect (a reduction of trade flows of GM products subject to a moratorium or a safeguard measure), but also from an indirect effect (measures against GM imports could also prevent the development and production of new GM products). Still, what is at stake in the WTO panel is the direct trade effect, and this is what we are interested in. The reduction in exports can be calculated by product, country of export and measure at stake. Of course, we consider that exports are reduced only if the coefficient estimated on GM measures in column (3) of Table 3 is significant.

The calculation is as follows: ${ }^{19}$ actual yearly flows are divided by the exponent of the coefficient estimate for the EU moratorium and/or specific measures from column (3) in Table 3. This gives us the amount of trade that would have taken place in the absence of the measures on GMOs. To obtain the revenue losses due to GM measures, we subtract actual flows from this amount. Using this method, we assume that the trade impact of GM measures is constant over time and that losses due to GM regulations do not affect prices of products that continue to be exported. Typically, we assume that if an exporter sets up an identity preserved export channel free of unapproved GMO events, prices and export costs are not affected. Results for the annual average revenues losses in the period 2003$2005^{20}$ are reported in Table 4.

Insert Table 4 here

The US is most affected by EU measures. The highest US revenue losses are observed for corn (seeds and other than seeds). Summing over all products, our estimations suggest that average annual US exports to the EU market between 2003 and 2005 have been US $\$ 1.97$ billion lower than they would have been in the absence of the EU moratorium, product-specific measures and national bans. For Canada and Argentina, the respective figures are US\$349.6 million and US\$52.2 million. To grasp

\footnotetext{
${ }^{19}$ A similar approach is used by Hufbauer et al. (1997) to calculate the trade impact of US economic sanctions.

${ }^{20}$ We estimate an annual trade reduction using the most recent statistics. As trade flows can fluctuate considerably from year to year, we use the average of the last available three years (2003-2005) for actual exports. Similar calculations can be done for the preceding years.
} 
the relative magnitude of these revenue losses, they can be compared to the average exports of maize, oilseed rape, cotton and corn gluten by the US, Canada and Argentina between 2003 and 2005. The revenue lost from the EU market represents $26.4 \%$ of average US exports of maize, oilseed rape, cotton and corn gluten between 2003 and 2005. For Canada and Argentina the respective shares are 28.1\% and 3.7\%. The small percentage for Argentina is largely explained by the fact that, since the beginning of the introduction of GM in agriculture, Argentina has only authorized the production of GMOs already approved by its main trading partners.

In our study, we did not consider potential export reorientation, mainly because it is not considered by the WTO Panel in its assessment of complainants' losses. The case treated at the WTO focuses only on the impact of EU and Member States' measures infringing SPS rules on complainants' exports to the EU. Since we restrict our analysis of export losses to the exact perimeter of the case, the omission of reorientation effects does not bias our estimations. Beyond the case, it might however be acknowledged that such a reorientation would reduce GM exporting countries' losses. Smyth et al. (2006) show that Canada's oilseed rape sales and US corn sales to the EU were shifted to other markets. Market losses occurred only over a short period, and globalization quickly offered new export opportunities to GM producers. More generally, it would be extremely difficult to assess the impact of such argument due to the absence of precise data on this phenomenon.

\section{Conclusion}

The purpose of this paper is to study the trade impact of EU measures on GMOs in the perspective of the WTO complaint of Argentina, Canada and the US. Since the WTO panel condemned first a general de facto moratorium on the approval of GMOs, second undue delays in the processing of product-specific applications, and third the inconsistency of the safeguard measures put in place by certain Member States, we took these three issues into account. Using the most recent advances in gravity equation estimation, we provided an estimation of losses in term of exports to the EU market by product, exporting country and measure at stake. Our findings tend to confirm the foundations of the dispute: revenue losses have been incurred by the complainants and these losses can be attributed to European (or Member State) decisions transgressing WTO rules. EU measures on GMOs reduce 
Argentina, Canada and US exports of the affected products on average, with effects varying across products and complainants. In total, yearly US revenue losses between 2003 and 2005 were US\$1.97 billion as compared with a counterfactual without the EU moratorium, product-specific measures and national bans. The respective numbers for Canada and Argentina are US\$349.6 million and US\$52.2 million.

Finally, departing from the strict framework of the WTO case, we also investigate the impact of non-approvals of GM products adopted by other countries, such as New Zealand, Switzerland and Norway, as well as the trade impact of EU measures on an exporting country that did not file a complaint, namely Brazil. The results provide refreshing insights into the case. We show that other importers than the EU have enforced trade-impeding measures on GMOs, while countries potentially negatively affected by European measures, such as Brazil for cotton, have not joined the WTO dispute. Such findings suggest that other determinants than revenue losses stricto sensu might have played a role in decisions as to whether to launch a case at the WTO. Ultimately, complaining countries must weigh up the costs and benefits of launching a panel. Two different issues must be considered here. Firstly, market size matters: it is worth bearing the costs of a very complex and long panel when the market concerned is very large, because the losses are very large too. From this point of view, the EU is certainly an ideal target for complainants, as opposed to Norway or New Zealand. Secondly, launching a panel at the WTO also sheds light on the policies pursued by the complainant. In the case of GMOs, this may be a very sensitive issue. Brazil could have been part of the case launched by Canada, the US and Argentina. However, it would have been an official recognition of the fact that Brazil was actually permanently growing GMOs, despite the temporary nature of the authorizations it had granted.

\section{Acknowledgments}

We especially appreciate the suggestions of Harmen Lehment and an anonymous referee. We thank participants at EEA 2008 and EAAE 2008 for helpful suggestions. 


\section{References}

Baldwin, R., \& Taglioni, D. (2006). Gravity for Dummies and Dummies for Gravity Equations. (NBER Working Paper 12516). National Bureau of Economic Research, Cambridge.

Brookes, G., \& Barfoot, P. (2006). GM Crops: The First Ten Years - Global Socio-Economic and Environmental Impacts. (ISAAA Brief 36). International Service for the Acquisition of Agri-biotech Applications, Ithaca.

Bullock, D. S., \& Desquilbet, M. (2002). The economics of non-GMO segregation and identity preservation. Food Policy, 27, 81-99.

Conrad, C. R. (2007). The EC-Biotech dispute and applicability of the SPS Agreement: Are the panel's findings built on shaky ground? World Trade Review, 6(2), 233-248.

Gruère, G. P. (2006). An Analysis of Trade Related International Regulations of Genetically Modified Food and their Effects on Developing Countries. (IFPRI Discussion Paper 147). International Food Policy Research Institute, Washington, DC.

Hufbauer, G. C., Elliott, K. A., Cyrus, T., Winston, E. (1997). US Economics Sanctions: Their Impact on Trade, Jobs, and Wages. (Peter G. Peterson Institute for International Economics Working Paper SPECIAL). Peter G. Peterson Institute for International Economics, Washington, DC.

James, C. (2008). Global Status of Commercialized Biotech/GM Crops: 2008. (ISAAA Brief 39). International Service for the Acquisition of Agri-biotech Applications, Ithaca.

Krugman, P. R. (1980). Scale economies, product differentiation and the pattern of trade. American Economic Review, 70(5), 950-959. 
Lapan, H. E., \& Moschini, G. (2004). Innovation and Trade with Endogenous Market Failure: The Case of Genetically Modified Products. American Journal of Agricultural Economics, 86(3), 634-648.

Martin, W., \& Pham, C. S. (2008). Estimating the Gravity Equation when Zero Trade Flows are Frequent. Manuscript, available at: http://mpra.ub.uni-muenchen.de/9453/

Moschini, G. (2008). Biotechnology and the development of food markets: retrospect and prospects. European Review of Agricultural Economics, 35(3), 331-355.

Moschini, G., Bulut, H., Cembalo, L. (2005). On the Segregation of Genetically Modified, Conventional and Organic Products in European Agriculture: A Multi-market Equilibrium Analysis. Journal of Agricultural Economics, 56(3), 347-372.

Perez, O. (2007). Anomalies at the precautionary kingdom: reflections on the GMO Panel's decision. World Trade Review, 6(2), 265-280.

Ramsey, J. B. (1969). Tests for Specification Errors in Classical Linear Least Squares Regression Analysis. Journal of the Royal Statistical Society, B31, 350-371.

Rauch, J. E. (1999). Networks versus markets in international trade. Journal of International Economics, 48(1), 7-35.

Redding, S., \& Venables, A. J. (2004). Economic geography and international inequality. Journal of International Economics, 62(1), 53-82.

Santos Silva, J. M. C., \& Tenreyro, S. (2006). The Log of Gravity. Review of Economics and Statistics, 88(4), 641-658. 
Santos Silva, J. M. C., \& Tenreyro, S. (2009). Further simulation evidence on the performance of the Poisson pseudo-maximum likelihood estimator. (University of Essex Discussion Paper 666). Department of Economics, University of Essex, Colchester.

Smyth, S., Kerr, W. A., Davey, K. A. (2006). Closing markets to biotechnology: does it pose an economic risk if markets are globalised? International Journal of Technology and Globalisation, 2(34), 377-389.

United States Department of Agriculture (2000). Biotechnology: Implications for U.S. Corn \& Soybean Trade. Washington, DC: USDA Economic Research Service.

World Trade Organization (1994). Agreement Establishing the World Trade Organization - Annex 2 Understanding on Rules and Procedures Governing the Settlement of Disputes. Geneva, CH: WTO.

World Trade Organization (2006). European Communities - Measures Affecting the Approval and Marketing of Biotech Products - Reports of the Panel. Geneva, CH: WTO. 
Table 1: GMOs events concerned by undue delays in the approval

\begin{tabular}{|c|c|c|c|c|c|}
\hline & $\begin{array}{l}\text { Introduction of } \\
\text { the application }\end{array}$ & EU approval & Argentina approval & Canada approval & US approval \\
\hline GA21 maize & Dec. 1997 & 2005 & 2005 & & 1996 \\
\hline Bt11 maize & April 1999 & & & & 1996 \\
\hline NK603 maize & Aug. 2000 & 2004 & 2004 & & 2000 \\
\hline Bt1507 maize & Feb. 2003 & 2005 & & & 2001 \\
\hline MS1/Rf1 oilseed rape & June 1997 & 2005 & & 1995 & \\
\hline MS1/Rf2 oilseed rape & June 1997 & 2005 & & 1995 & \\
\hline MS8/Rf3 oilseed rape & Jan. 1997 & 2005 & & 1996 & 1996 \\
\hline Liberator oilseed rape & Oct. 1998 & & & & 1995 \\
\hline RR oilseed rape & Jan. 2003 & 2005 & & 1994 & 1995 \\
\hline Bt-531 cotton & Nov. 1997 & 2005 & 1998 & & 1995 \\
\hline RR1445 cotton & Nov. 1997 & 2005 & 2001 & & 1995 \\
\hline BXN cotton & May 1999 & & & & 1994 \\
\hline
\end{tabular}

Sources: Date of introduction of the application:

www.europa.eu/rapid/pressReleasesAction.do?reference=MEMO/03/221\&format=PDF\&aged=1\&language=FR \&guiLanguage $=e n$. Approval by the US, Canada, Argentina, and the EU: Agbios database www.agbios.com/dbase.php 
Table 2: GMOs events concerned by national safeguard measures

\begin{tabular}{ccccc}
\hline & $\begin{array}{c}\text { Initiation date of } \\
\text { the ban }\end{array}$ & Argentina approval & $\begin{array}{c}\text { Canada } \\
\text { approval }\end{array}$ & US approval \\
\hline Austria - T25 maize & May 2000 & 1998 & 1996 & 1995 \\
Austria - Bt176 maize & Feb. 1997 & 1998 & & 1995 \\
Austria - MON810 maize & June 1999 & 1998 & & 1996 \\
France - MS1/Rf1 oilseed rape & Nov. 1998 & & 1995 & 1996 \\
France - Topas oilseed rape & Nov. 1998 & & 1995 & 1995 \\
Germany - Bt176 maize & April 2000 & 1998 & & 1995 \\
Greece - Topas oilseed rape & Nov. 1998 & & 1995 & 1995 \\
Italy - Bt11 maize & August 2000 & 2001 & 1996 & 1996 \\
Italy - MON810 maize & August 2000 & 1998 & 1997 & 1996 \\
Italy - MON809 maize & August 2000 & & 1996 & 1996 \\
Italy - T25 Maize & August 2000 & 1998 & 1996 & 1995 \\
Luxembourg - Bt176 Maize & March1997 & 1998 & & 1995 \\
\hline
\end{tabular}

Sources: Initiation dates of bans:

www.europa.eu/rapid/pressReleasesAction.do?reference=MEMO/03/221\&format=PDF\&aged=1\&language=FR \&guiLanguage=en. Approval by the US, Canada and Argentina: Agbios database www.agbios.com/dbase.php 
Table 3: Influence of measures on GMOs

\begin{tabular}{|c|c|c|c|c|c|c|}
\hline \multirow{3}{*}{$\begin{array}{l}\text { Dependent variable } \\
\text { Model } \\
\text { Ln distance }\end{array}$} & \multicolumn{6}{|c|}{ Imports } \\
\hline & \multicolumn{2}{|c|}{ (1) } & \multicolumn{2}{|c|}{ (2) } & \multicolumn{2}{|l|}{ (3) } \\
\hline & $-1.85 * * *$ & $(0.29)$ & $-1.85 * * *$ & $(0.29)$ & $-1.85 * * *$ & $(0.29)$ \\
\hline Common border & 0.19 & $(0.50)$ & 0.18 & $(0.50)$ & 0.17 & $(0.50)$ \\
\hline Common language & 0.05 & $(0.20)$ & 0.03 & $(0.19)$ & 0.03 & $(0.19)$ \\
\hline EU morat. and/or spec. meas. on maize seeds & $-2.24 * * *$ & $(0.56)$ & & & & \\
\hline on Canada's exports & & & $-3.94 * * *$ & $(0.68)$ & $-3.95 * * *$ & $(0.68)$ \\
\hline on US exports & & & $-2.14 * * *$ & $(0.59)$ & $-2.15 * * *$ & $(0.59)$ \\
\hline EU morat. and/or spec. meas. on maize (other) & $-1.24^{*}$ & $(0.67)$ & & & & \\
\hline on Argentina's exports & & & 0.96 & $(0.63)$ & 0.95 & $(0.63)$ \\
\hline on Canada's exports & & & $-4.68 * * *$ & $(0.47)$ & $-4.70 * * *$ & $(0.47)$ \\
\hline on US exports & & & $-3.43 * * *$ & $(0.39)$ & $-3.44 * * *$ & $(0.39)$ \\
\hline EU morat. and/or spec. meas. on oilseed rape & $-5.17 * * *$ & $(0.68)$ & & & & \\
\hline on Canada's exports & & & $-3.32 * * *$ & $(0.59)$ & $-3.33 * * *$ & $(0.59)$ \\
\hline on US exports & & & $-7.58 * * *$ & $(0.34)$ & $-7.59 * * *$ & $(0.34)$ \\
\hline EU morat. and/or spec. meas. on cotton seeds & $-4.10 * * *$ & $(0.75)$ & & & & \\
\hline on Argentina's exports & & & $-5.01 * * *$ & $(0.88)$ & $-5.03 * * *$ & $(0.88)$ \\
\hline on US exports & & & $-4.02 * * *$ & $(0.81)$ & $-4.03 * * *$ & $(0.81)$ \\
\hline on Brazil's exports & & & & & $-5.37 * * *$ & $(0.91)$ \\
\hline $\begin{array}{l}\text { EU morat. and/or spec. meas. on starch } \\
\text { residues }\end{array}$ & $-1.22 * * *$ & $(0.37)$ & & & & \\
\hline on Canada's exports & & & $-6.10 * * *$ & $(1.13)$ & $-6.14 * * *$ & $(1.12)$ \\
\hline on US exports & & & $-1.11 * * *$ & $(0.38)$ & $-1.14 * * *$ & $(0.38)$ \\
\hline $\begin{array}{l}\text { EU morat. and/or spec. meas. on preparations } \\
\text { used in animal feeding }\end{array}$ & $-0.64 *$ & $(0.37)$ & & & & \\
\hline on Canada's exports & & & $-2.32 * * *$ & $(0.61)$ & $-2.35 * * *$ & $(0.60)$ \\
\hline on US exports & & & -0.55 & $(0.40)$ & -0.56 & $(0.40)$ \\
\hline Austria's ban on maize seeds & 0.83 & $(0.78)$ & 0.85 & $(0.77)$ & 0.85 & $(0.77)$ \\
\hline Austria's ban on maize (other) & -0.88 & $(0.75)$ & -1.02 & $(1.04)$ & -1.02 & $(1.04)$ \\
\hline Germany's ban on maize seeds & $-3.56 * * *$ & $(0.69)$ & $-3.55 * * *$ & $(0.67)$ & $-3.56 * * *$ & $(0.67)$ \\
\hline Germany's ban on maize (other) & $-3.05 * * *$ & $(0.65)$ & $-3.29 * * *$ & $(1.14)$ & $-3.29 * * *$ & $(1.14)$ \\
\hline Italy's ban on maize seeds & -0.87 & $(0.94)$ & -0.81 & $(0.91)$ & -0.82 & $(0.91)$ \\
\hline Italy's ban on maize (other) & $-1.94 * *$ & $(0.91)$ & $-2.30 * * *$ & $(0.62)$ & $-2.30 * * *$ & $(0.63)$ \\
\hline France's ban on oilseed rape & $-1.82 * * *$ & $(0.67)$ & -1.61 & $(1.10)$ & -1.61 & $(1.10)$ \\
\hline Greece's ban on oilseed rape & $-3.53 * *$ & $(1.50)$ & $-3.27 * * *$ & $(0.57)$ & $-3.27 * * *$ & $(0.57)$ \\
\hline New Zealand's morat. on maize seeds & & & & & $-1.08 *$ & $(0.58)$ \\
\hline New Zealand's morat. on maize (other) & & & & & -0.39 & $(0.59)$ \\
\hline New Zealand's morat. on oilseed rape & & & & & $-4.93 * * *$ & $(0.56)$ \\
\hline New Zealand's morat. on soybeans & & & & & $-2.93 * * *$ & $(1.02)$ \\
\hline Switzerland's morat. on maize (other) & & & & & -0.87 & $(0.61)$ \\
\hline Switzerland's morat. on soybeans & & & & & 1.03 & $(0.40)$ \\
\hline Norway's non-approv. on maize (other) & & & & & $-1.82 * *$ & $(0.92)$ \\
\hline Norway's non-approv. on soybeans & & & & & -0.18 & $(0.72)$ \\
\hline Observations \& reset test $p$-values & $57,552 \&$ & 0.360 & $57,552 \&$ & 0.374 & $57,552 \&$ & 0.374 \\
\hline
\end{tabular}


Table 4: Average annual export revenue losses due to European measures on GMOs 2003-2005 (thousand US dollars)

\begin{tabular}{|c|c|c|c|}
\hline & Argentina & Canada & United States \\
\hline & \multicolumn{3}{|c|}{ HS 100510 - Maize (seeds) } \\
\hline EU moratorium and/or specific measures & & $68,441.9$ & $471,603.0$ \\
\hline \multirow{2}{*}{ Germany's safeguard measure } & $2,531.5$ & 2,329.9 & $29,209.5$ \\
\hline & \multicolumn{3}{|c|}{ HS 100590 - Maize (other) } \\
\hline EU moratorium and/or specific measures & & $103,031.3$ & $379,652.3$ \\
\hline Germany's safeguard measure & $5,641.5$ & 948.4 & $22,059.5$ \\
\hline \multirow[t]{2}{*}{ Italy's safeguard measure } & $8,360.3$ & 175.0 & $5,718.3$ \\
\hline & \multicolumn{3}{|c|}{ HS 120500 - Oilseed rape (seeds and other) } \\
\hline EU moratorium and/or specific measures & & $34,769.3$ & $266,937.3$ \\
\hline \multirow[t]{2}{*}{ Greece's safeguard measure } & 0 & 111.4 & 0 \\
\hline & \multicolumn{3}{|c|}{ HS 120720 - Cotton seeds } \\
\hline \multirow[t]{2}{*}{ EU moratorium and/or specific measures } & $35,628.3$ & & $381,626.3$ \\
\hline & \multicolumn{3}{|c|}{ HS 230310 - Starch residues } \\
\hline EU moratorium and/or specific measures & & $64,457.1$ & $411,595.9$ \\
\hline EU moratorium and/or specific measures & \multicolumn{3}{|c|}{$\begin{array}{c}\text { HS } 230990 \text { - Preparations used in animal feeding } \\
75,383.7\end{array}$} \\
\hline
\end{tabular}

